\title{
Carbon exchange over four growing seasons for a subarctic sedge fen in northern Manitoba, Canada
}

\begin{tabular}{|r|l|}
\hline Journal: & Arctic Science \\
\hline Manuscript ID & AS-2015-0003.R2 \\
\hline Manuscript Type: & Article \\
\hline Date Submitted by the Author: & 20 -Aug-2015 \\
\hline Complete List of Authors: & $\begin{array}{l}\text { Hanis, Krista; University of Manitoba, Soil Science } \\
\text { Amiro, Brian; University of Manitoba, Soil Science } \\
\text { Tenuta, Mario; University of Manitoba, Soil Science } \\
\text { Papakyriakou, Tim; University of Manitoba, Environment \& Geography } \\
\text { Swystun, Kyle; University of Manitoba, Environment \& Geography }\end{array}$ \\
\hline Keyword: & fen, peat, carbon flux, eddy covariance, Hudson Bay \\
\hline & \multicolumn{2}{|l}{} \\
\hline
\end{tabular}




\title{
Carbon exchange over four growing seasons for a subarctic sedge fen in northern Manitoba, Canada
}

\author{
Krista L. Hanis ${ }^{1}$, Brian D. Amiro ${ }^{1}$, Mario Tenuta ${ }^{1 *}$, Tim Papakyriakou ${ }^{2}$, and Kyle A. Swystun ${ }^{2,3}$ \\ ${ }^{1}$ Department of Soil Science, University of Manitoba, Winnipeg, Manitoba, R3T 2N2, Canada \\ ${ }^{2}$ Department of Environment and Geography, University of Manitoba, Winnipeg, Manitoba, R3T 2N2, Canada \\ ${ }^{3}$ Current address: Alberta Agriculture and Rural Development, Edmonton, Alberta, T6E 5K1, Canada \\ *Corresponding author: mario.tenuta@umanitoba.ca, 204-474-7827.
}

\begin{abstract}
Net ecosystem exchange of carbon (NEE) was measured using eddy covariance for four growing seasons at a subarctic hummocky fen in northern Manitoba, Canada. Over a 115-day measurement period each year, cumulative NEE ranged from a gain of $49 \mathrm{~g} \mathrm{C} \mathrm{m}^{-2}$ to a loss of 16 $\mathrm{g} \mathrm{C} \mathrm{m}^{-2}$ with a mean loss of $6 \mathrm{~g} \mathrm{C} \mathrm{m}^{-2}$ from the fen, with an uncertainty of about $\pm 34 \mathrm{~g} \mathrm{C} \mathrm{m}^{-2}$. Ecosystem respiration decreased with higher water tables $\left(\mathrm{r}^{2}=0.3\right)$, especially in one summer when flooding occurred to $0.12 \mathrm{~m}$ above the peat surface. Additional methane emissions previously documented for the site of 4 to $5.7 \mathrm{~g} \mathrm{C} \mathrm{m}^{-2} \mathrm{y}^{-1}$ added to the carbon loss. Carbon loss was measured from this same fen in the 1990s and it is likely that the carbon gain (peat accumulation) during past centuries has not continued in recent decades. Scaling to annual greenhouse gas emissions as a 100-year global warming potential showed that this fen is currently a source of 192 to $490 \mathrm{~g} \mathrm{CO}_{2}$-equivalents $\mathrm{m}^{-2} \mathrm{y}^{-1}$ based on both carbon dioxide and methane flux measurements, indicating that peat is decomposing.
\end{abstract}

Key Words: fen, peat, flux, carbon, eddy covariance, methane, Hudson Bay 


\section{Introduction}

The Canadian arctic hosts $1 / 3$ of the circumpolar tundra (Bliss and Matveyeva 1992) and is rich in soil organic carbon (C). Tarnocai et al. (2009) estimated that the top $1 \mathrm{~m}$ of circumpolar arctic soil has approximately $500 \mathrm{Gt}$ C, $12-25 \%$ of the global total. The Hudson Bay Lowlands is especially important because it is the second largest peatland complex in the northern hemisphere (Gorham 1991). Changes in climatic conditions, such as altered air temperature and precipitation patterns, could have significant effects on this stored $\mathrm{C}$ and the net ecosystem exchange of carbon dioxide (NEE) of arctic environments over diurnal to decadal to millennial timescales. NEE is the balance between the photosynthetic uptake of carbon dioxide (gross primary production, GPP) and ecosystem respiration (ER). In arctic and subarctic peatlands, cool summer soil temperatures and saturated soils due to the presence of permafrost generally cause slow rates of decomposition and heterotrophic respiration (Clymo 1984). Therefore, although these regions have low GPP compared to boreal, temperate and tropical regions, their GPP often exceeds ER, creating a downward (negative) NEE to store C over long periods.

The carbon dynamics of northern peatlands are driven by changes in temperature and water table level, but these drivers tend to have site-specific relationships partly caused by the hydrological regime, and partly caused by the vegetation composition and nature of the ecosystem response. For example, ER at the Mer Bleue bog in central Canada depended more on temperature $\left(r^{2}=0.6\right)$ than on water table depth $\left(r^{2}=0.1\right)$, but this is a relatively dry bog (Lafleur et al. 2005). At a fen in central Alberta, Canada, Cai et al. (2010) reported that although both GPP and ER increased with warmer temperatures, ER increased more, which decreased net C uptake. At a subarctic fen at Churchill, Manitoba underlain by continuous permafrost, Burton et al. (1996) reported GPP and ER increased with warmer and drier conditions in late 
July compared to cooler and wetter conditions in early August of 1993. Schreader et al. (1996) reported a net loss of $22 \mathrm{~g} \mathrm{C} \mathrm{m}^{-2}$ under unprecedented warm and dry conditions at the Churchill fen in the summer of 1994 (hottest and driest growing season in 50 years). They suggested GPP was unaffected but ER increased during this year.

Frolking et al. (2011) summarized a large number of peatland studies where temperature and water table effects were measured. Although there was variability in response, NEE typically had less $\mathrm{C}$ uptake under warmer temperatures and more uptake with lower water tables. There are only a few peatland sites where annual NEE has been measured over several years. Lund et al. (2010) evaluated seven wetland sites from Europe and North America where full years of NEE measurements were made using eddy covariance ( 24 site years). The sites were $\mathrm{C}$ sinks on average with NEE of $-103 \mathrm{~g} \mathrm{C} \mathrm{m}^{-2} \mathrm{y}^{-1}$, but had highly variable relationships of GPP and ER components with NEE. However, long-term work in Alaska indicates that some ecosystems have changed from $\mathrm{C}$ sources to sinks, with water table lowering being a contributing factor (Oechel et al. 1993; Oechel and Vourlitis 1994).

These general observations are captured in models of the $\mathrm{C}$ dynamics of peatlands. For example, the CLASS wetland model dictates that $\mathrm{C}$ cycling in bogs and fens is more sensitive to temperature than precipitation (Wu et al. 2012), and a Holocene peat model estimates that drier periods have caused loss of $\mathrm{C}$ during the Holocene (Frolking et al. 2010). These models have been used to estimate the likely changes that may occur in future climates (Frolking et al. 2011). Some model results suggest that fens are more sensitive than bogs to climate change, and that fens may become $\mathrm{C}$ sources in the future (Wu and Roulet 2014). 
In Canada, multi-year flux studies of both NEE and methane have been conducted at the Mer Bleue bog near Ottawa, and the Western Peatlands fen in Alberta. These sites use eddy covariance to measure fluxes over a broad footprint (Chen et al. 2012). Both of these peatlands were typically C sinks with NEE of the order of more than $-100 \mathrm{~g} \mathrm{C} \mathrm{m}^{-2} \mathrm{y}^{-1}$ at the fen (Syed et al. 2006, Long et al. 2010) and $-40 \mathrm{~g} \mathrm{C} \mathrm{m}^{-2} \mathrm{y}^{-1}$ at the bog (Roulet et al. 2007), but neither have permafrost. Methane emissions were on the order of 2 to $4 \mathrm{~g} \mathrm{C} \mathrm{m}^{-2} \mathrm{y}^{-1}$ (Roulet et al. 2007, Long et al. 2010). In addition to these sites, extensive flux studies have taken place in permafrostdominated landscapes in the Northwest Territories (Lafleur and Humphreys 2008, Humphreys and Lafleur 2011), in the Hudson Bay Lowlands (Humphreys et al. 2014), and at a subarctic fen at Churchill, Manitoba, Canada. The Churchill studies began in the 1990s (Burton et al. 1996; Schreader et al. 1998; Griffis et al. 2000a; Griffis et al. 2000b; Lafleur et al. 2001; Rouse et al. 2002) and have periodic continuity to recent years, although the methods have changed from gradient techniques to eddy covariance. At this same subarctic fen near Churchill, we previously reported the seasonal dynamics of methane fluxes for 2008 to 2011 measured using eddy covariance (Hanis et al. 2013). In the current study, we report on NEE over the same period and the greenhouse gas budget (including methane) for this site. We investigate the driving forces contributing to variability in NEE among years, hypothesizing that the fen is affected by both temperature and water table changes. Lastly, we retrospectively evaluate if NEE has changed over approximately two decades, mindful of the uncertainty of our ability to discern differences among relatively small fluxes that occur over this peatland.

\section{Data and Methods}


STUDY SITE

The study site is a subarctic palsa fen (NWWG, 1997) near Churchill, Manitoba, Canada (58 39' 57" N, 93 49' 48" W) located approximately $10 \mathrm{~km}$ inland from the Hudson Bay coastline. It is within the zone of continuous permafrost (Brown 1970), and the active layer can extend to a depth of more than $1.5 \mathrm{~m}$ by early fall. The fen is comprised of hummocks, sedgelawns, and hollows having up to $40 \mathrm{~cm}$ of peat over carbonate-rich glaciomarine sediments (Rouse et al. 2002). Although we do not have peat measurements at this fen, peat development has occurred for over 6000 years in the area (Kuhry 2008). The fen is about 1.7 x $1.3 \mathrm{~km}$ in size.

The sedge-lawns cover approximately $55 \%$ of the fen (Raddatz et al. 2009) and are dominated by the sedge Carex aquatilis Wahlenb and an understory of the moss, Pseudocalliergon turgescens (Jensen) Loeske. Other sedges, cotton grass, rushes, and horsetails are also present (Hanis et al. 2013). New shoots of $C$. aquatilis emerge shortly after spring melt from mid- to late-June, flowering occurs in mid-July and senescence begins in late-August. The sedge-lawns are situated at the mean water-table, peat-surface interface (sedge-peat surface) with P. turgescens being submersed during periods of a high water table (often June, September and October), and exposed during periods of a low water table (often July and August).

The hummocks are drier mounds that rise about $40 \mathrm{~cm}$ above the sedge-peat surface. They are dominated by Cladina spp. and Cladonia spp. of lichens, and the moss Dicranum elongatum Schwaegr. Low shrubs of Betula glandulosa Michx., Salix arctophila Cock. ex Heller, Rhododendron spp., and Vaccinium spp. are also present. The hollows are about $30 \mathrm{~cm}$ below the sedge-peat surface with mats of $P$. turgescens and partially decomposed peat material at their base, overlying a mineral substrate. They usually are filled with water except during extreme drought periods. 
During our observation period, the water table typically fluctuated from $15 \mathrm{~cm}$ below to 20 $\mathrm{cm}$ above the mean sedge-peat surface (used as datum; mean elevation $=16.56$ m.a.s.1 with S.D. $= \pm 0.4$ and $n=29)$ throughout the ice-free season. The maximum water table height usually occurred just after the onset of spring snow-melt: 26 May (day of year (DOY) 146) 2007, 23 May (DOY 144) 2008, 9 May (DOY 129) 2010 and 30 May (DOY 150) 2011. The water table was also high in the fall, and freezing of open water typically occurred over a 5- to 10-day period, from a thin skiff of ice that melted during midday (onset of freeze-up) to an ice layer thick enough to walk on without breaking through (full freeze-up). The freeze-up periods, from onset to full freeze-up, were 24 - 27 October (DOY 297 - 300) 2007, 19 - 26 October (DOY 293 - 300) 2008, 17 - 30 October (DOY 290 - 303) 2010 and 18 - 23 October (DOY 291 - 296) 2011.

\section{DATA COLLECTION}

Two eddy covariance flux towers were located near the centre of the fen. NEE was measured at Station 1 in 2007 and 2008. Both NEE and methane flux $\left(\mathrm{F}_{\mathrm{CH} 4}\right)$ were measured at Station 2, located 90 m northeast of Station 1, during the 2008, 2010 and 2011 field seasons. The vegetation surrounding each tower was similar such that the sampling footprints represented similar parts of the landscape. Large data gaps in the 2009 field season due to problems with logging of $\mathrm{CO}_{2}$ concentrations and power supply made this year unreliable for NEE and is excluded from our analysis. NEE data used in this study was from Site 1 in 2007 and 2008, and Site 2 in 2010 and 2011. There was good agreement between NEE for the stations overlap of operations in 2008 (Tower 2 NEE $\mu \mathrm{mol} \mathrm{m} \mathrm{m}^{-1} 30^{-\min }$ periods $=0.97 *$ Tower $1 \mathrm{NEE}-0.84, \mathrm{r} 2$ $=0.60, \mathrm{n}=367$, at friction velocity $>0.2 \mathrm{~m} \mathrm{~s}^{-1}$ and Tair $>5^{\circ} \mathrm{C}$ ). Both stations were off-grid. 
Station 1 was powered by three photovoltaic panels for $300 \mathrm{~W}$ combined, and Station 2 was powered by wind (Model 200 Whisper Wind Generator, Southwest Windpower Inc., Flagstaff, AZ), solar (five photovoltaic panels for $500 \mathrm{~W}$ combined), and gas power generation (EU2000i, Honda Inc. as supplemental).

At each station, a 3-dimensional ultrasonic anemometer-thermometer (CSAT3, Campbell Scientific Inc., Logan, UT) was used to measure wind velocities and air temperature. Water vapour and $\mathrm{CO}_{2}$ molar density were measured using an open-path $\mathrm{CO}_{2} / \mathrm{H}_{2} \mathrm{O}$ analyzer (LI-7500, LI-COR Biosci., Lincoln, NE). Station 1 collected data at a $20 \mathrm{~Hz}$ frequency whereas Station 2 collected at a $10 \mathrm{~Hz}$ frequency. At Station 1, the CSAT3 and LI-7500 were installed on a mast at a height of $3.9 \mathrm{~m}$ above the fen's surface facing due north, separated by $20 \mathrm{~cm}$ horizontal distance and oriented perpendicular to the ground surface. At Station 2, the CSAT3 and LI-7500 were installed on a mast extending outwards from the northwest corner of a $4.5 \mathrm{~m}$ high scaffold at a height of $4.3 \mathrm{~m}$ above the fen's surface facing due north. The CSAT3 was perpendicular to the ground surface, while the LI-7500 was center-mounted at a $35^{\circ}$ angle with a minimum horizontal separation of $20 \mathrm{~cm}$ from the CSAT3. The atmospheric methane concentration was measured using a closed-path analyzer (RMT-200 Fast Methane Analyzer (Los Gatos Research Inc., Mountain View, CA) (Baer et al. 2002; Hendriks et al. 2008; Baldocchi et al. 2011) at 10 Hz frequency. A detailed description of the RMT-200 set-up is given in Hanis et al. (2013).

A meteorological tower at Station 1 measured environmental variables half-hourly during all field seasons from 2007 to 2011. Air temperature was measured at a height of $1.8 \mathrm{~m}$ (HMP45C, Vaisala Inc., Woburn, MA, with radiation shield). Horizontal wind speed and direction were measured at a height of $4 \mathrm{~m}$ (Model 05103, R.M. Young Co., Traverse City, MI), and incoming photosynthetically active radiation (PAR) was measured at $1 \mathrm{~m}$ (PAR Lite sensor, Kipp \& 
Zonen, Bohemia, NY). A tipping-bucket rain gauge (TR-525M, Texas Electronics Inc., Dallas, TX) measured rainfall at $0.5 \mathrm{~m}$ above the sedge-peat surface. Near-surface soil temperature was measured by averaging type-T thermocouples placed at a 5-cm depth in three hummocks, sedgelawns and hollows. Water table height was read daily from stationary rulers in three hollows during all four field seasons, and recorded half hourly by three pressure transducers (HOBO U20 Water Level Data Loggers, Onset Computer Corporation, Inc., Pocasset, MA) in the 2008 and 2011 field seasons. Elevation of ruler tops and the sedge-peat surface (29 locations) were determined by GPS (TSC1 Asset Surveyor, Trimble Navigation Ltd., Sunnyvale, CA).

\section{DATA ANALYSIS}

Half-hourly eddy covariance fluxes were calculated for $\mathrm{NEE}$ and $\mathrm{F}_{\mathrm{CH} 4}$ using MATLAB (R2007a, The Math Works Inc., Natick, MA) user-defined functions. Spikes in the measured high-frequency data were removed based on thresholds to identify single spurious values. Blockaverage covariances were calculated without detrending and then coordinate rotated for each 30min period (Tanner and Thurtell 1969). The covariances were maximized half-hourly by adjusting lag delays. Density effects were corrected for both heat and water vapour for the openpath $\mathrm{CO}_{2}$ systems (Webb et al., 1980). Self-heating of the LI-7500 analyzer was included based on the corrections (Method 4) of Burba et al. (2008). However during frozen periods when conditions should have been respiration-dominated, our 30-min fluxes often showed a net uptake of $\mathrm{CO}_{2}$ by the ecosystem. This phenomenon has been well documented at other cold sites (Amiro 2010), so we excluded measurements of NEE when the air temperature was below $0^{\circ} \mathrm{C}$ prior to gap-filling. This accounted for $4 \%$ of the data over the four seasons. 
NEE data were filtered when rain and particles intercepted the sensor path based on the analyzer's diagnostic report. NEE determinations were also filtered to remove half-hour periods at night $\left(\mathrm{PAR}<10 \mu \mathrm{mol} \mathrm{m} \mathrm{s}^{-2}\right.$ ) when the friction velocity was below a threshold of $0.2 \mathrm{~m} \mathrm{~s}^{-1}$ (Hanis et al. 2013). All NEE from Station 2 were also filtered to remove half-hourly periods when the wind direction was $135-225^{\circ}$ to exclude directions from the tower and gas-powered generator. Filtering of $\mathrm{F}_{\mathrm{CH} 4}$ is described in Hanis et al. (2013). After data filtering for periods with low friction velocity, as well as other quality control checks, data coverage for the study period (DOY 170 - 284) for NEE was $59 \%$ in $2007,74 \%$ in $2008,36 \%$ in 2010 , and $45 \%$ in 2011. Data coverage for $\mathrm{F}_{\mathrm{CH} 4}$ at Station 2 was $2 \%$ in $2008,11 \%$ in 2010 and $7 \%$ in 2011.

Small data gaps of up to two hours for NEE and $\mathrm{F}_{\mathrm{CH} 4}$ were filled using linear interpolation between 30-min averaged fluxes. Larger gaps in NEE were filled using the method of the Fluxnet Canada Research Network (Barr et al. 2004) using a 100-point moving-window centered on the known 30-min fluxes. This method calculates ER as a function of 5-cm-depth soil temperature $\left(T_{s}\right)$, and GPP as a function of incoming PAR based on regression relationships. The governing equations are:

$$
\mathrm{GPP}=p(t) \alpha Q P /(\alpha Q+P)
$$

where $p(t)$ is a parameter that varies in time representing the short-term fluctuations of GPP with incoming PAR, $Q . \alpha$ represents quantum yield and $P$ is GPP at light saturation.

$$
\mathrm{ER}=a(t) b /\left[1+\exp \left(c\left(d-T_{s}\right)\right]\right.
$$

where $a(t)$ is a parameter that varies in time representing the short-term fluctuations in ER with $T_{s}$. Parameters $b, c$, and $d$ are curve-fit constants. Note that when the short-term time- 
varying parameters in Equations (1) and (2) are removed, the functions calculate the slower response to driving environmental variables $\left(Q, T_{S}\right)$ allowing seasonal trends to be examined.

GPP was set to zero at night and when the air temperature was below $0^{\circ} \mathrm{C}$. Missing NEE was then resolved using calculated ER and GPP. We found that this method under-estimated ER in spring and fall during periods when the sedge vegetation had senesced and temperatures were warm, so we adjusted ER during these periods by allowing ER = NEE (i.e., GPP could not be a $\mathrm{C}$ loss). Larger gaps in $\mathrm{F}_{\mathrm{CH} 4}$ were filled by using a linear regression between $\mathrm{F}_{\mathrm{CH} 4}$ and $T_{s}$ as described in Hanis et al. (2013). This relationship had an $\mathrm{r}^{2}$ of 0.95 for the temperature range of 0 to $15^{\circ} \mathrm{C}$. Since $\mathrm{F}_{\mathrm{CH} 4}$ was not measured during the 2007 season, it was modelled using this same regression to estimate the contribution of $\mathrm{F}_{\mathrm{CH} 4}$ to the overall carbon and greenhouse gas budgets for the fen.

The common observational period when NEE was measured during all four study years was the 115 days from 19 June (DOY 170) to 11 October (DOY 284). Although we focus on this period for the present comparison, it is instructive to estimate annual fluxes for this ecosystem. Hence, NEE and $\mathrm{F}_{\mathrm{CH} 4}$ were modelled for the remaining parts of the year when frozen conditions dominated (DOY $1-169$ and 285 - 366). For $\mathrm{F}_{\mathrm{CH} 4}$, we assumed a flux of zero for this period, as demonstrated by Hanis et al. (2013) for frozen conditions. For NEE, night-time fluxes were regressed against air temperature for periods between 0 and $10^{\circ} \mathrm{C}$. The exponential relationship of $\mathrm{NEE}=1.07 \times 10^{-15} \mathrm{e}^{0.1218^{*} \mathrm{~T}}$ (where NEE is in $\mu \mathrm{mol} \mathrm{m} \mathrm{m}^{-2} \mathrm{~s}^{-1}$ and $\mathrm{T}$ is degrees $\mathrm{K} ; \mathrm{r}^{2}=0.76$ ) was extended for colder temperatures (e.g., normal January mean air temperature $=-26^{\circ} \mathrm{C}$ ). We recognize that this is a rough approximation over the frozen season, but we only use it to estimate annual carbon and greenhouse gas budgets. Atmospheric gains are defined as positive 
fluxes. Calculations of global warming potential for methane used a factor of 28 on a mass basis over a 100-year timescale (Myhre et al. 2013).

\section{Results}

\section{ENVIRONMENTAL CONDITIONS}

Seasonal environmental conditions from the nearby Churchill airport (Table 1) indicated that 2007 was warmer and drier than the 1981 - 2010 climate normal (Environment Canada, 2014) from May until July, followed by a cooler-than-normal trend through August and September, with continued drier-than-normal conditions in August. In 2008, spring-melt (May) and midsummer (July) conditions were drier than normal, followed by a warmer- and wetter-than-normal August, and a drier-than-normal fall (September to November). In 2010, wetter-than-normal conditions were present from spring-melt to late growing season (May to August), with July being warmer than normal and August being cooler than normal. Fall conditions (September to November) were drier and warmer than normal. The 2011 study period was cooler than normal in May and then warmer than normal from the peak of the growing season until late fall (July to November). Normal precipitation occurred in the early and peak growing season (June and July), whereas wetter-than-normal conditions were present in August and October, and drier-thannormal conditions occurred in September and November. Overall temperature was coolest in 2007 and warmest in 2011, but all years were warmer than the 1981-2010 normal.

The lowest precipitation and water table position occurred in 2008, whereas the highest precipitation and water table positions were mostly in 2010 (Fig. 1). A major rainfall event on DOY 236 of 2010 brought $110 \mathrm{~mm}$ in 24 hours and raised the water table $12 \mathrm{~cm}$ above the peat 
surface, resulting in total inundation of sedge-lawn vegetation. Heavy rains from DOY $280-290$ of 2011 inundated the fen just prior to freeze-up.

\section{NET ECOSYSTEM EXCHANGE OF CARBON}

Cumulative gap-filled NEE ( $\mathrm{NNEE}$ ) shows the seasonal pattern in C gains and losses over the four years (Fig. 2). In 2007, $\Sigma \mathrm{NEE}$ was positive (loss of $\mathrm{CO}_{2}$ to the atmosphere) until DOY 186, and then the fen began to take up $\mathrm{CO}_{2}$ until DOY 230, after which there was little change for the remainder of the measurement period. In 2008, loss of $\mathrm{CO}_{2}$ to the atmosphere occurred until DOY 188, and then the fen began to take up $\mathrm{CO}_{2}$ until DOY 222. In mid-summer there was another net loss of $\mathrm{CO}_{2}$ from DOY 223 - 229, followed by uptake from DOY $230-242$, and finally, net loss from DOY 243 until the end of the measurement period. In 2010, there was a net loss of $\mathrm{CO}_{2}$ until DOY 190, followed by $\mathrm{CO}_{2}$ uptake until DOY 220, then a period of little change until DOY 253, after which a large loss occurred to the end of the measurement period. The rapid period of NEE changing from uptake to neutrality in 2010 at about DOY 230 to 240 coincided with the large precipitation event and water table rise (Fig. 1). In 2011, loss of $\mathrm{CO}_{2}$ to the atmosphere occurred until DOY 183 , followed by a large uptake until DOY 252, and then a slow loss of $\mathrm{CO}_{2}$ compared to other years for the remainder of the measurement period. There was greater cumulative $\mathrm{CO}_{2}$ uptake in 2011 compared to the other years. Over the study period of DOY $170-284$, $\Sigma \mathrm{NEE}$ was $-6.5 \mathrm{~g} \mathrm{C} \mathrm{m}^{-2}$ in $2007,+16.5 \mathrm{~g} \mathrm{C} \mathrm{m}^{-2}$ in $2008,+16.1 \mathrm{~g} \mathrm{C} \mathrm{m}^{-2}$ in 2010, and $-48.9 \mathrm{~g} \mathrm{C} \mathrm{m}^{-2}$ in 2011 (Fig. 2).

We evaluated uncertainty by considering four sources of variability. First, we assumed that the flux calculation uncertainty was about 5\% (e.g., Elbers et al. 2011) or $0.6 \mathrm{~g} \mathrm{C} \mathrm{m}^{-2}$ on average. Next we evaluated the uncertainty caused by the use of the heating correction of Burba et al. 
(2008). On an annual basis in cold environments, this correction can give differences of NEE of about $150 \mathrm{~g} \mathrm{C} \mathrm{m}^{-2}$ compared to no correction (Amiro 2010). For our fen site during the growing season, the mean difference for the four years was $34 \pm 5.4$ (S.D.) $\mathrm{g} \mathrm{C} \mathrm{m}^{-2}$, where the correction makes NEE more positive (i.e., it is a bias that decreases $\mathrm{C}$ uptake). We have assumed that using the correction is preferable to ignoring it, but we acknowledge that the gas analyser at our Station 2 was on an angle that was not consistent with the intended geometry, so that the correction has additional uncertainty that depends on wind direction. The third source of uncertainty was the selection of the $\mathrm{u} *$ threshold. This was difficult to define because of the scatter in the small NEE values, and we used a value of $0.2 \mathrm{~m} \mathrm{~s}^{-1}$ to be consistent with Hanis et al. (2013) at the same site. If we used a value of $0.1 \mathrm{~m} \mathrm{~s}^{-1}$ instead, carbon loss increased by 1 to 17 (S.D. $\left.=7.6\right) \mathrm{g} \mathrm{C} \mathrm{m}^{-2}$, depending on year. The fourth source of error was gapfilling, which causes uncertainty of the order of 30 to $100 \mathrm{~g} \mathrm{C} \mathrm{m}^{-2}$ on an annual basis for many ecosystems (Baldocchi 2008). Our data retention was 51\% over the four years, with more gaps in 2010 and 2011 because of the exclusion of wind directions where a generator was located. The gaps tended to be interspersed throughout the season, except for a 10-day period missing near DOY 270 in 2007. Cumulative growing-season NEE using only the quality-controlled measurements was $7.9 \pm 33.0 \mathrm{~g} \mathrm{C} \mathrm{m}^{-2}$ greater than when the gaps were filled, on average over the four years. For comparison, if we assumed that gaps had zero NEE, the average difference was $11 \mathrm{~g} \mathrm{C} \mathrm{m}^{-2}$. Combining these uncertainties, the root of the sum of the squares of S.D. for individual terms $(0.6,5.4,7.6,33 \mathrm{~g} \mathrm{C}$ $\mathrm{m}^{-2}$ ) yields an overall uncertainty of $34 \mathrm{~g} \mathrm{C} \mathrm{m}^{-2}$ for the 115-day growing season. Note that we have not adjusted NEE to account for potential underestimation of the turbulent flux, as indicated by lack of energy budget closure. This could increase the flux by about 15 to $20 \%$ (e.g., Wilson et al. 2002). 
Partitioning of NEE into GPP and ER (gapfilled) allows for examination of the environmental effects on ecological processes. In all years, our study period captured the period of growth (GPP $>0$; note that our convention for GPP is positive when the ecosystem gains carbon) (Fig. 3). Following Coursolle et al. (2012), we defined the start and end point of the growing season based on the threshold when the running mean of GPP was greater than $15 \%$ of the yearly mean daily maximum GPP for five consecutive days. Growing season start and end dates were 178 and 253 (75 days) in 2007, 182 and 260 (78 days) in 2008, 168 and 251 (83 days) in 2010, and 181 and 255 (74 days) in 2011, very similar among years, with 2010 being the longest season. The large precipitation event on DOY 236 in 2010 abruptly decreased GPP to near zero, whereas ER had a slight lag, but the high water table kept both processes near zero until it lowered by at least $10 \mathrm{~cm}$ over the following week (Fig. 1). This period was an anomaly because GPP recovered more than ER initially, whereas ER continued at a relatively high rate after the end of the growing season (post DOY 253). We examined the seasonal trends in GPP and ER through the slow-response functions in Equations (1) and (2); i.e., removing $p(t)$ and $a(t)$ to plot the moving window (Fig. 4). Note that this removes individual 30-min responses to temperature and radiation that are included in Fig. 3. The maximum GPP response occurs between DOY 200 and 230 in each year, much later than the solstice (DOY 172), showing the need for sedge phenological development for maximum response. About DOY 240, 2010 shows low GPP response whereas 2008 shows high GPP response, consistent with high (2010) and low (2008) water tables (Fig 1). Among the four years, the slow response of ER is most different in 2010, showing low response with high water table about DOY 240, with a recovery and compensation about DOY 270, when the water table lowered. There was a significant negative linear relationship between slow ER response with water table height for all years $\left(r^{2}=0.30 ; n=\right.$ 
192, $\mathrm{P}<0.001)$. This relationship was significant $(\mathrm{P}<0.02)$ for individual years except for 2008 $(\mathrm{P}=0.7)$

The 2011 year had the greatest carbon sequestration (Fig. 2) that was driven by greater total GPP during the study period: $144 \mathrm{~g} \mathrm{C} \mathrm{m}^{-2}$, compared to 104,104 and $107 \mathrm{~g} \mathrm{C} \mathrm{m}^{-2}$ in 2007, 2008, and 2010, respectively. Cumulative ER varied from 95 to $123 \mathrm{~g} \mathrm{C} \mathrm{m}^{-2}$ among years, with the highest value in 2010 and the lowest in 2011. Cumulative gap-filled $\mathrm{F}_{\mathrm{CH} 4}\left(\Sigma \mathrm{F}_{\mathrm{CH} 4}\right)$ was $4.3 \mathrm{~g} \mathrm{C} \mathrm{m}^{-}$ ${ }^{2}\left(160 \mathrm{~g} \mathrm{CO}_{2}\right.$-eq m$\left.{ }^{-2}\right)$ in 2008, $4.2 \mathrm{~g} \mathrm{C} \mathrm{m}^{-2}\left(159 \mathrm{~g} \mathrm{CO}_{2}\right.$-eq $\left.\mathrm{m}^{-2}\right)$ in 2010 and $4.8 \mathrm{~g} \mathrm{C} \mathrm{m}^{-2}(181 \mathrm{~g}$ $\mathrm{CO}_{2}$-eq m$\left.{ }^{-2}\right)$ in 2011, and modelled as $4.0 \mathrm{~g} \mathrm{C} \mathrm{m}^{-2}\left(151 \mathrm{~g} \mathrm{CO}_{2}\right.$-eq $\left.\mathrm{m}^{-2}\right)$ in 2007. Accounting for both carbon dioxide and methane, the net $\mathrm{C}$ budget of the study period showed the fen to be a sink of $-2.5 \mathrm{~g} \mathrm{C} \mathrm{m}^{-2}$ in 2007, a source of $20.8 \mathrm{~g} \mathrm{C} \mathrm{m}^{-2}$ in 2008 , a source of $20.4 \mathrm{~g} \mathrm{C} \mathrm{m}^{-2}$ in 2010 and a sink of $-44.1 \mathrm{~g} \mathrm{C} \mathrm{m}^{-2}$ in 2011 . When the global warming potential of methane is considered (factor of 28, Myhre et al. 2013), the fen was a net greenhouse gas source for the measurement period for three years: $127 \mathrm{~g} \mathrm{CO}_{2}$-eq $\mathrm{m}^{-2}$ in $2007,221 \mathrm{~g} \mathrm{CO}_{2}$-eq $\mathrm{m}^{-2}$ in $2008,215 \mathrm{~g} \mathrm{CO}_{2}$-eq m${ }^{-2}$ in 2010, but a sink of $1 \mathrm{~g} \mathrm{CO}_{2}$-eq $\mathrm{m}^{-2}$ in 2011 (Fig. 5).

\section{Discussion}

\section{WATER TABLE AND TEMPERATURE AS DRIVERS OF NEE}

The dynamic nature of the water table level provides an opportunity to evaluate effects on NEE. Flooding occurred when the water table was near or above the 0 -cm datum, during the periods DOY 170 - 200 in 2007 and DOY 230 - 265 in 2010 (Fig.1). For the spring 2007 period, there was no clear evidence that NEE, GPP and ER were affected by this water table height that would distinguish this year from the other years (Figs. 2, 3). However, the August flooding in 2010 inhibited both GPP and ER (Fig. 4), resulting in very small NEE for a few 
weeks. The increase of the slow-response respiration function after the flooding event in 2010 was likely because of ample detrital substrate that now had sufficient aeration for decomposition. However, 2008 had a high ER after about DOY 260 even though the water table was lower (Figs. 1, 3, 4). Similarly, we could look at dry periods, defined when the water table was below about $-10 \mathrm{~cm}$. This happened through much of 2008 (DOY $180-230$ ) and for a short period in 2011 (DOY 270 - 280) (Fig. 1). For 2008, NEE was small for the period DOY 180 - 205 after which a small increase in the water table appeared to alleviate the stress. Most of the cumulative C loss in spring 2007 happened between DOY 170 and 180, when water table levels were similar to 2010 and 2011. The dry period in fall 2011 may have decreased ER, when compared to 2008 and 2010 (Fig. 3). However the water table was high in fall 2007 and NEE was similar between 2007 and 2011, so it is not clear that the ER reduction in 2011 was caused by this water level. Similarly, total seasonal precipitation (Table 1) did not show a clear relationship with $\Sigma$ NEE because 2008 was much drier than 2010, even though $\Sigma$ NEE was identical. These time series observations for individual years describe specific responses to water table height. Overall, ER decreased with higher water tables, but this only explained $30 \%$ of the variability. Phenological development affects autotrophic respiration and substrate available for decomposition, and variability among years seems to occur mostly in spring and autumn, with the exception of the flooding in 2010 (Fig. 4).

Temperature effects can be evaluated by looking at both the spring and fall influences on NEE and its components. The large ER in spring 2008 from about DOY 170 to 190 (Fig. 3) cannot be attributed to obviously higher June temperatures (Table 1) and a plot of cumulative temperature over time does not show this spring to be warmer than other years (data not shown). For the fall period, 2010 has large ER from about DOY 255 - 284, but this cannot be attributed 
to temperature given that September 2011 was warmer and did not show this large ER (Table 1, Figs. 2, 3). Lafleur and Humphreys (2008) and Humphreys and Lafleur (2011) showed a strong correlation between the number of growing degree days and early-season NEE for a wet sedge fen site in the low Arctic at Daring Lake, Northwest Territories, Canada. At Churchill, Griffis et al. (2000a) and Lafleur et al. (2001) also showed that earlier melt resulted in a larger uptake of $\mathrm{CO}_{2}$ over the 1994 to 1999 growing seasons. In our study, snowmelt occurred $15-21$ days earlier in 2010 than the other three study years, and this translated into an earlier growing season by 10 to 14 days. Despite this early start in 2010, $\Sigma$ NEE did not become C neutral until about DOY 210, identical to 2007, and slower than in 2011 (Fig. 2). The comparative response among years is most easily seen in Fig. 4 with a higher slow-response GPP function in spring of 2008 and 2010; this function excludes PAR differences among years and reflects phenology and other drivers, such as temperature (PAR is the only environmental driver in Equation 1).

Extreme events, such as a very high or low water table, have shown differences among years. At the same fen in 1993, Burton et al. (1996) found that ER was nearly three times higher during a dry period (July 18 - 29) than a wet period (July 30 - August 24) but the water level differences might have been more drastic than those that we observed. Similarly, a drought period in 1994 at the fen at Churchill was $2^{\circ} \mathrm{C}$ warmer and rainfall was 55\% lower than normal so that the water table dropped $25-30 \mathrm{~cm}$ below the mean sedge-peat surface; this decreased NEE to only $-0.05 \mathrm{~g} \mathrm{C} \mathrm{m}^{-2} \mathrm{~d}^{-1}$ during the peak growing period of June 22 - Aug 8 (Schreader et al. 1998). Rouse et al. (2002) reported on five years of NEE for the fen at Churchill in the late 1990 's and found that the years with the largest $\mathrm{CO}_{2}$ uptake by the ecosystem had warmer-thannormal air temperature and normal to wetter-than-normal precipitation, which supports our observations during the 2011 study period. At the Churchill fen, mosses contribute to NEE, but 
likely have the most impact in the spring before the sedges develop (Griffis et al. 2000b), or perhaps later after the sedges senesce. Dry periods would adversely affect moss photosynthesis, but we cannot see any spring or fall impact on GPP that could be attributed to inhibited moss function, possibly because there was adequate water at those times. Clearly, sedge development dominates GPP because the response function peaks much later than the solstice, even though mosses can photosynthesize earlier (Fig. 4).

Observations of water-level effects on NEE at other peatlands usually have greater contrasts. For example, Aurela et al. (2007) showed a decline in the $\mathrm{CO}_{2}$ sink capacity of a boreal sedge fen in southern Finland during the drought summer of 2005, compared to 2004. Chivers et al. (2009) manipulated the water table in experimental plots within a moderate rich sedge fen near Fairbanks, Alaska and found a smaller $\mathrm{CO}_{2}$ sink for the drought-induced plots compared to the control plots, attributed to reduced photosynthesis of both vascular plants and non-vascular mosses. Similarly, Peichl et al. (2014) found that exceptional years were needed for NEE to change from its mean value over 12 years of measurements in a boreal fen in Sweden. They showed that very low water tables increased late season respiration, thereby decreasing the $\mathrm{CO}_{2}$ sink. Humphreys et al. (2014) determined a greater reduction in GPP than ER at their bog in northern Ontario during a mid-season lowering of the water table. Riutta et al. (2007) found that the sedge Carex lasiocarpa became moisture stressed in a boreal oligotrophic fen without permafrost in southern Finland when the water table went $15 \mathrm{~cm}$ below the surface. Chivers et al (2009) also found low water tables decreased photosynthesis in the dominant vascular species Carex atherodes, Carex canescens, Potentilla palustris, and Equisetum fluviatile in a boreal sedge fen in central Alaska. This would also likely happen for our Carex aquatilis at the 
subarctic fen at Churchill, but the water table would likely need to drop more than it did during our measurement years.

\section{THE CARBON AND GREENHOUSE GAS SINK VERSUS SOURCE POTENTIAL}

The subarctic fen at Churchill had a net NEE accumulation for the 115-day study period ranging from -49 to $16 \mathrm{~g} \mathrm{C} \mathrm{m}^{-2}$, with an average of $-6 \mathrm{~g} \mathrm{C} \mathrm{m}^{-2}$ (Fig. 2). We estimate our overall uncertainty to be about $34 \mathrm{~g} \mathrm{C} \mathrm{m}^{-2}$, indicating that only 2011 was different from $\mathrm{C}$ neutrality during the growing season. Previous studies at the same Churchill fen from June to August, 1993 to 1999 (average measurement period of 68 days) reported cumulative NEE ranging from 64 to $22 \mathrm{~g} \mathrm{C} \mathrm{m}^{-2}$, with an average of $-18 \mathrm{~g} \mathrm{C} \mathrm{m}^{-2}$ (Burton et al. 1996; Schreader et al. 1998; Griffis et al. 2000a; Griffis et al. 2000b; Lafleur et al. 2001). For the same period of mid-June to late August in our four years, $\Sigma \mathrm{NEE}$ ranged from -47 to $-5 \mathrm{~g} \mathrm{C} \mathrm{m}^{-2}$ with an average of $-21 \mathrm{~g} \mathrm{C} \mathrm{m}^{-}$

${ }^{2}$. This similarity over approximately a decade suggests no trend in ecosystem changes over time.

Humphreys et al. (2014) studied two northern bogs in the same Hudson Bay Lowlands, about $700 \mathrm{~km}$ from our site. They measured net NEE over two years (2010-2012) of about $-50 \mathrm{~g} \mathrm{C} \mathrm{m}^{-2}$ $\mathrm{y}^{-1}$; these bogs were moss and shrub dominated and quite different from our sedge-dominated fen. At Daring Lake, Northwest Territories, located within the low arctic zone and underlain with continuous permafrost, Lafleur and Humphreys (2008) and Humphreys and Lafleur (2011) measured a net $\mathrm{CO}_{2}$ sink for mid-May to late August in 2004 to 2010 (109 days per year). They reported mean daily NEE ranging from -0.75 to $-0.30 \mathrm{~g} \mathrm{C} \mathrm{m}^{-2} \mathrm{~d}^{-1}$ with an average of $-0.57 \mathrm{~g} \mathrm{C} \mathrm{m}^{-}$ ${ }^{2} \mathrm{~d}^{-1}$ for mesic lichen-heath mat tundra, and a wet sedge fen values ranged from -1.01 to $-0.58 \mathrm{~g}$ $\mathrm{C} \mathrm{m}^{-2} \mathrm{~d}^{-1}$ with an average of $-0.79 \mathrm{~g} \mathrm{C} \mathrm{m}^{-2} \mathrm{~d}^{-1}$. Both the mesic lichen-heath mat tundra and wet sedge fen at Daring Lake appear to be more productive than our subarctic sedge fen at Churchill, 
but their measurements did not extend into the fall when ecosystem respiration exceeds photosynthesis. Mean daily NEE for arctic sedge tundra at Prudhoe Bay, Alaska was $-0.15 \mathrm{~g} \mathrm{C}$ $\mathrm{m}^{-2} \mathrm{~d}^{-1}$ from June to August 1994 (90 days) and $-0.13 \mathrm{~g} \mathrm{C} \mathrm{m}^{-2} \mathrm{~d}^{-1}$ from May to September 1995 (90 days) (Vourlitis and Oechel 1997). Vourlitis et al. (2000) found a greater uptake over arctic wet sedge tundra underlain by continuous permafrost at Happy Valley, on the north slope of Alaska, for 92 days in June to August of 1995 with a mean daily NEE of $-0.84 \mathrm{~g} \mathrm{C} \mathrm{m}^{-2} \mathrm{~d}^{-1}$. These sites are drier than the Churchill fen, so the carbon dynamics are quite different. However, the Alaska sites still had a net annual carbon loss once winter respiration was considered (Oechel et al. 2000).

For global carbon budget estimates, we require full annual estimates of greenhouse gas exchange. This is clearly a challenge in these northern environments where most direct measurements have only been during the growing season. To arrive at an annual total for $1994-$ 1999 at the Churchill fen, Rouse et al. (2002) used an over-winter emission rate of $0.14 \mathrm{~g} \mathrm{C} \mathrm{m}^{-2}$ $\mathrm{d}^{-1}$ for the snow-cover period, based on Zimov et al. (1993) for Siberian tundra soils. This gave cumulative annual NEE of -31 to $54 \mathrm{~g} \mathrm{C} \mathrm{m}^{-2} \mathrm{y}^{-1}$. However, this Siberia estimate was based on loamy mineral soil, not organic soil characteristic of our site. Instead, we used our regression relationship between measured NEE and soil temperature at the $5-\mathrm{cm}$ depth to fill the winter period. The average winter flux estimates were $0.19 \mathrm{~g} \mathrm{C} \mathrm{m}^{-2} \mathrm{~d}^{-1}$ for $2007,0.18 \mathrm{~g} \mathrm{C} \mathrm{m}^{-2} \mathrm{~d}^{-1}$ for 2008, $0.25 \mathrm{~g} \mathrm{C} \mathrm{m}^{-2} \mathrm{~d}^{-1}$ for 2010 , and $0.17 \mathrm{~g} \mathrm{C} \mathrm{m}^{-2} \mathrm{~d}^{-1}$ for 2011 . These cumulative winter emissions of $49 \mathrm{~g} \mathrm{C} \mathrm{m}^{-2}$ for 2007, $44 \mathrm{~g} \mathrm{C} \mathrm{m}^{-2}$ for $2008,63 \mathrm{~g} \mathrm{C} \mathrm{m}^{-2}$ for 2010 and $43 \mathrm{~g} \mathrm{C} \mathrm{m}^{-2}$ for 2011 increase $\mathrm{C}$ loss so the resulting annual totals for NEE were 42, 61, 79 and $-6 \mathrm{~g} \mathrm{C} \mathrm{m}^{-2} \mathrm{y}^{-1}$ for 2007, 2008, 2010 and 2011 respectively. The variability in winter emissions among years was $\pm 9.2 \mathrm{~g} \mathrm{C} \mathrm{m}^{-2}$ (1 S.D.) and this uncertainty is additive with the summer variability of $\pm 34 \mathrm{~g} \mathrm{C} \mathrm{m}^{-2}$ 
yielding a total annual uncertainty of $\pm 43 \mathrm{~g} \mathrm{C} \mathrm{m}^{-2} \mathrm{y}^{-1}$. This indicates a likely annual source in 2008 and 2010, and carbon neutrality in 2007 and 2011. We acknowledge the large uncertainty in winter emissions, but these estimates are only slightly greater than direct winter measurements in Alaska of about $38 \mathrm{~g} \mathrm{C} \mathrm{m}^{-2}$ (Oechel et al. 2014). These winter emissions play a large role in the annual carbon budget so direct winter NEE measurements would help reduce the uncertainty in annual totals. Full carbon accounting also needs to consider possible lateral gains or losses of dissolved carbon, both in organic and inorganic forms. Dissolved organic carbon concentrations measurements have been made in the general Churchill area (Edwards and Jeffries 2013), but no fluxes have been estimated for our fen. Measurements elsewhere suggest a range of $2 \mathrm{~g} \mathrm{C} \mathrm{m}^{-2} \mathrm{y}^{-1}$ from a permafrost plateau (Olefeldt and Roulet 2014) to $15 \mathrm{~g} \mathrm{C} \mathrm{m}^{-2} \mathrm{y}^{-1}$ measured in a temperate bog (Roulet et al. 2007). Assuming that lateral inputs of inorganic and organic $\mathrm{C}$ in water are small, this fen has been losing $\mathrm{C}$ in recent decades based on our measurements and those from the 1990 s, which indicates that some subarctic wetlands are currently carbon sources. However, historic peat accumulation may have occurred during periods of higher water tables, which inhibits respiration.

The methane emissions add to the net greenhouse gas flux, especially with the global warming potential of 28 times that of $\mathrm{CO}_{2}$ over a 100-year timescale (Myhre et al. 2013). Thus, small emissions of methane with respect to the carbon budget ( 4.0 to $5.7 \mathrm{~g} \mathrm{C} \mathrm{m}^{-2} \mathrm{y}^{-1}$ ) have larger implications to the overall annual greenhouse gas budget (emissions of 151 to $213 \mathrm{~g} \mathrm{CO}_{2}$-eq m${ }^{-2}$ $\left.\mathrm{y}^{-1}\right)$. Therefore, when taking methane into account, the fen was an annual greenhouse gas source of $305,406,490$ and $192 \mathrm{~g} \mathrm{CO}_{2}$-eq $\mathrm{m}^{-2} \mathrm{y}^{-1}$ in 2007, 2008, 2010 and 2011 respectively. 


\section{Conclusions}

The measurement of whole-ecosystem carbon and methane fluxes is a challenge in ecosystems where these fluxes are small. In cold, remote environments, these challenges are even more difficult and measurements are often only attempted during the warmer parts of the year. This causes uncertainty that is often in the range of the actual fluxes, such that the definition of sources or sinks, or the attribution of environmental drivers, must be evaluated cautiously. Within the uncertainty, the subarctic fen at Churchill, Manitoba, was a carbon sink during the growing season in only one of four years. High water table heights generally decreased respiration, especially during one particularly wet event in 2010 that decreased both photosynthesis and respiration. The weather was generally not that much different among years, and there were few extremes that generated large ecosystem responses. An early snowmelt in one year did not translate into increased carbon uptake during the growing season.

Winter respiration is an important feature for the carbon budget of arctic ecosystems, and we estimated that 43 to $63 \mathrm{~g} \mathrm{C} \mathrm{m}^{-2} \mathrm{y}^{-1}$ was lost in winter. Once we include winter respiration, the fen was carbon neutral in 2007 and $2011\left( \pm 43 \mathrm{~g} \mathrm{C} \mathrm{m}^{-2} \mathrm{y}^{-1}\right)$ but lost from 61 to $79 \mathrm{~g} \mathrm{C} \mathrm{m}^{-2} \mathrm{y}^{-1}$ in 2008 and 2010, for a marginal average loss of $44 \mathrm{~g} \mathrm{C} \mathrm{m}^{-2} \mathrm{y}^{-1}$. Losses were also measured during the 1990s, suggesting that recent decades are different from the periods of earlier carbon accumulations by this peatland. Once we include the carbon lost through methane emissions, we estimate that this fen contributed an average of $49 \mathrm{~g} \mathrm{C} \mathrm{m}^{-2} \mathrm{y}^{-1}$ and $348 \mathrm{~g} \mathrm{CO}_{2}$-eq m $\mathrm{m}^{-2} \mathrm{y}^{-1}$ during the four years. Scaling of the large area of northern peatlands with different measurements of carbon and methane exchange will be a challenge for global modellers. 


\section{Acknowledgements}

We thank staff, researchers and volunteers of the Churchill Northern Studies Centre for field support, J.O. Rapai and G.J. Scott for technical support, Z. Nesic (and others at UBC), A. Barr and M. Gervais for software development and support. Funding was provided by the Natural Sciences and Engineering Council of Canada (NSERC) Discovery Program, the Canada Foundation for Innovation, the Canada Research Chair Program in Applied Soil Ecology and ArcticNet Network of Centres of Excellence of Canada. K. Hanis was supported by a NSERC Post-graduate scholarship, the Weston Award for Northern Research, the Northern Scientific Training Program, the Environment Canada Science Horizons Program and the Churchill Northern Studies Centre Northern Research Fund. 


\section{References Cited}

Amiro, B.D. 2010. 'Estimating annual carbon dioxide eddy fluxes using open-path analysers for cold forest sites', Agricultural and Forest Meteorology, vol. 150, pp. 1366-1372.

Aurela, M., Laurila, T., and Tuovinen, J.P. 2004. 'The timing of snow melt controls the annual $\mathrm{CO}_{2}$ balance of a subarctic fen', Geophysical Research Letters, vol. 31, LI6119, 4pp.

Aurela, M., Riutta, T., Laurila, T., Tuovinen, J,P., Vesala, T., Tuittila, E.S., Rinne, J., Haapanala, S. and Laine, J. 2007. ' $\mathrm{CO}_{2}$ exchange of a sedge fen in southern Finland - the impact of a drought period', Tellus, vol. 59B, pp. 826-837.

Baer, D.S., Paul, J.B., Gupta, M., and O’Keefe, A. 2002. 'Sensitive absorption measurements in the near-infrared region using off-axis integrated-cavity-output spectroscopy', Applied Physics B: Laser and Optics, vol. 75, pp. 261-265.

Baldocchi, D.D. 2008. “'Breathing' of the terrestrial biosphere: lessons learned from a global network of carbon dioxide flux measurement systems' Australian Journal of Botany, vol. 56 , pp. 1-26.

Baldocchi, D., Detto, M., Sonnentag, O., Verfaillie, J., Teh, Y.A., Silver, W., and Kelly, N.M. 2011. 'The challenges of measuring methane fluxes and concentrations over peatland pasture', Agricultural and Forest Meteorology, vol. 153, pp. 177-187, doi:10.1016/j.agrformet.2011.04.013.

Barr, A.G., Black, T.A., Hogg, E.H., Kljun, N., Morgenstern, K., and Nesic, Z. 2004. 'Interannual variability in the leaf area index of a boreal aspen-hazelnut forest in relation to net ecosystem production', Agricultural and Forest Meteorology, vol. 126, pp. 237-255. 
Bliss, L.C., and Matveyeva, N.V, 1992. 'Circumpolar Arctic vegetation' in Arctic Ecosytems in a Changing Climate, An Ecological Perspective, eds FS Chapin, RL Jefferies, JF Reynolds, GR Shaver \& J Svoboda, Academic Press, New York, pp. 58-89.

Brown, R.J.E. 1970. Permafrost in Canada; its influence on Northern development, University of Toronto Press, Toronto.

Burba, G.G., McDermitt, D.K., Grelle, A., Anderson, D.J., and Xu, L. 2008. 'Addressing the influence of instrument surface heat exchange on the measurements of $\mathrm{CO}_{2}$ from openpath gas analyzers', Global Change Biology, vol. 14, pp. 1854-1876.

Burton, K.L., Rouse, W.R., and Boudreau, L.D. 1996. 'Factors affecting the summer carbon dioxide budget of a subarctic wetland tundra', Climate Research, vol. 6, pp. 203-213.

Cai, T., Flanagan, L.B., and Syed, K.H. 2010. 'Warmer and drier conditions stimulate respiration more than photosynthesis in a boreal peatland ecosystem: Analysis of automatic chambers and eddy covariance measurements', Plant, Cell and Environment, vol. 33, pp. 394-407.

Chen, B., Coops, N.C., Fu, D., Margolis, H.A., Amiro, B.D., Black, T.A., Arain, M.A., Barr, A.G., Bourque, C.P.A., Flanagan, L.B., Lafleur, P.M., McCaughey, J.H., and Wofsy, S.C .2012., 'Characterizing spatial representativeness of flux tower eddy-covariance measurements across the Canadian Carbon Program Network using remote sensing and footprint analysis', Remote Sensing of the Environment, vol. 124, pp. 742-755.

Chivers, M.R., Turetsky, M.R., Waddington, J.R., Harden, J.W. and McGuire, A.D. 2009. 'Effects of experimental water table and temperature manipulations on ecosystem $\mathrm{CO}_{2}$ fluxes in an Alaskan rich fen', Ecosystems, vol. 12, pp.1329-1342. 
Clymo, R.S. 1984. 'The limits to peat bog growth', Philosophical Transactions of the Royal Society B, vol. 303, pp. 605-654.

Coursolle, C., Margolis, H.A., Giasson, M.A., Bernier, P.Y., Amiro, B.D., Arain, M.A., Barr, A.G., Black, T.A., Goulden, M.L., McCaughey, J.H., Chen, J.M., Dunn, A.L., Grant, R.F., and Lafleur, P.M. 2012. 'Influence of stand age on the magnitude and seasonality of carbon fluxes in Canadian forests', Agricultural and Forest Meteorology, vol. 165, pp. 136-148.

Detto, M., Verfaillie, J., Anderson, F., Xu, L., and Baldocchi, D. 2011. 'Comparing laser-based open- and closed-path gas analyzers to measure methane fluxes using the eddy covariance method', Agricultural and Forest Meteorology, vol. 151, pp. 1312-1324.

Edwards, K.A., and Jeffries, R.L. 2013. 'Inter-annual and seasonal dynamics of soil microbial biomass and nutrients in wet and dry low-Arctic sedge meadows', Soil Biology \& Biochemistry, vol. 57, pp. 83-90.

Elbers, J.A., Jacobs, C.M.J. B., Kruijt, B., Jans, W.W.P., and Moors, E.J., 2011. 'Assessing the uncertainty of estimated annual totals of net ecosystem productivity: A practical approach applied to a mid latitude temperate pine forest'. Agricultural and Forest Meteorology vol. 151, pp. $1823-1830$.

Environment Canada 2014. National climate data and information archive. Available from: $<$ http://www.climate.weatheroffice.gc.ca $>$ [10 November 2014].

Frolking, S., Roulet, N.T., Tuittila, E., Bubier, J.L., Quillet, A., Talbot, J., and Richard, P.J.H. 2010. 'A new model of Holocene peatland net primary production, decomposition, water balance, and peat accumulation', Earth System Dynamics, vol. 1, pp.1-21. 
Frolking, S., Talbot, J., Jones, M.C., Treat, C.C., Kauffman, J.B., Tuittila, E.S. and Roulet, N. 2011. 'Peatlands in the Earth's 21st century climate system', Environmental Reviews, vol. 19, pp. 371-396.

Golovatskaya, E.A., and Dyukarev, E.A. 2009. 'Carbon budget of oligotrophic mire sites in the southern taiga of western Siberia', Plant Soil, vol. 315, pp. 19-34.

Gorham, E. 1991. 'Northern peatlands: Role in the carbon cycle and probable responses to climatic warming' Ecological Applications, vol. 1, pp. 182-195.

Griffis, T., and Rouse, W.R. 2001. 'Modelling the interannual variability of net ecosystem $\mathrm{CO}_{2}$ exchange at a subarctic fen', Global Change Biology, vol. 7, pp. 511:530.

Griffis, T., Rouse, W.R., and Waddington, J.M. 2000a. 'Interannual variability of net ecosystem $\mathrm{CO}_{2}$ exchange at a subarctic fen', Global Biogeochemical Cycles, vol. 14, pp. 1109-1121.

Griffis, T., Rouse, W.R., and Waddington, J.M. 2000b. 'Scaling net ecosystem $\mathrm{CO}_{2}$ exchange from the community to landscape-level at a subarctic fen', Global Change Biology, vol. 6, pp. 459-473.

Hanis, K.L., Tenuta, M., Amiro, B.D., and Papakyriakou, T.N. 2013. 'Seasonal dynamics of methane emissions from a subarctic fen in the Hudson Bay Lowlands', Biogeosciences, vol. 10, pp. $4465-4479$.

Hendriks, D.M.D., Dolman, A.J., van der Molen, M.K., and van Huissteden, J. 2008. 'A compact and stable eddy covariance set-up for methane measurements using off-axis integrated output spectroscopy', Atmospheric Chemistry and Physics, vol. 8, pp. 431-443. 
Humphreys, E.R., and Lafleur, P.M. 2011. 'Does earlier snowmelt lead to greater $\mathrm{CO}_{2}$ sequestration in two low Arctic tundra ecosystems?', Geophysical Research Letters, vol. 38, LO9703, 5 pp.

Humphreys, E.R., Charron, C., Brown, M., and Jones, R. 2014. 'Two bogs in the Canadian Hudson Bay Lowlands and a temperate bog reveal similar annual net ecosystem exchange of $\mathrm{CO}_{2}{ }^{\prime}$. Arctic, Antarctic, and Alpine Research, vol. 46, pp. 103-113.

Lafleur, P.M., Griffis, T.J., and Rouse, W.R. 2001. 'Interannual variability in net ecosystem $\mathrm{CO}_{2}$ exchange at the arctic treeline', Arctic, Antarctic, and Alpine Research, vol. 33, no.2, pp. 149-157.

Lafleur, P.M., Moore, T.R., Roulet, N.T., and Frolking, S. 2005. 'Ecosystem respiration in a cool temperate bog depends on peat temperature but not water table', Ecosystems, vol. 8, pp. $619-629$.

Lafleur, P.M., and Humphreys, E.R., 2008. 'Spring warming and carbon dioxide exchange over low Arctic tundra in central Canada', Global Change Biology, vol. 14, pp. 740-756.

Long, K.D., Flanagan, L.B., and Cai, T. 2010. 'Diurnal and seasonal variation in methane emissions in a northern Canadian peatland measured by eddy covariance', Global Change Biology, vol. 16, pp. 2420-2435.

Lund, M., Lafleur, P.M., Roulet, N.T., Lindroth, A., Christensen, T.R., Aurela, M., Chojnicki, B.H., Flanangan, L.B., Humphreys, E.R., Laurila, T., Oechel, W.C., Olejnik, J., Rinne, J., Schubert, P., and Nilsson, M.S.B. 2010. 'Variability in exchange of $\mathrm{CO}_{2}$ across 12 northern peatland and tundra sites', Global Change Biology, vol. 16, pp. 2436-2448. 
McFadden, J.P., Eugster, W., and Chapin, F.S. III. 2003. 'A regional study of the controls on water vapor and $\mathrm{CO}_{2}$ exchange in arctic tundra', Ecology, vol. 84, pp. 2762-2776.

National Wetlands Working Group 1997. The Canadian Wetland Classification System: Second Edition, Wetland Research Centre, University of Waterloo, Ontario.

Myhre, G., Shindell, D., Bréon, F-M., Collins, W., Fuglestvedt, J., Huang, J., Koch, D., Lamarque, J-F., Lee, D., Mendoza, B., Nakajima, T., Robock, A., Stephens, G., Takemura, T., and Zhang, H. 2013. 'Anthropogenic and natural radiative forcing'. In: Climate Change 2013: The Physical Science Basis. Contribution of Working Group I to the Fifth Assessment Report of the Intergovernmental Panel on Climate Change [Stocker, T.F., D. Qin, G.-K. Plattner, M. Tignor, S.K. Allen, J. Boschung, A. Nauels, Y. Xia, V. Bex and P.M. Midgley (eds.)]. Cambridge University Press, Cambridge, United Kingdom and New York, NY, USA.

Oechel W.C., and Vourlitis, G.L. 1994. 'The effects of climate change on land-atmosphere feedbacks in arctic tundra regions', Trends in Ecology and Evolution, vol. 9, pp. 324-329.

Oechel, W.C., Hastings, S.J., Vourlitis, G.L., Jenkins, M., Riechers, G., and Grulke, N. 1993. 'Recent changes of Arctic tundra ecosystems from a net carbon dioxide sink to a source', Nature, vol. 361, pp. 520-523.

Oechel, W.C., Vourlitis, G.L., Hastings, S.J., Zulueta, R.C., Hinzman, L., and Kane, D. 2000. 'Acclimation of ecosystem $\mathrm{CO}_{2}$ exchange in the Alaskan Arctic in response to decadal climate warming', Nature, vol. 406, pp. 978-981. 
Oechel, W.C., Laskowski, C.A., Burba, G., Gioli, B., and Kalhori, A.A.M. 2014. 'Annual patterns and budget of $\mathrm{CO} 2$ flux in an Arctic tussock tundra ecosystem', Journal of Geophysical Research Biogeosciences., vol. 119, pp. 323-339, doi:10.1002/2013JG002431.

Olefeldt, D., and Roulet, N. 2014. 'Permafrost conditions in peatlands regulate magnitude, timing, and chemical composition of catchment dissolved organic carbon export', Global Change Biology, vol. 20, pp. 3122-3136.

Peichl, M., Öquist, M., Löfvenius, M.O., Ilstedt, U., Sagerfors, J., Grelle, A., Lindroth, A., and Nilsson, M.B. 2014. 'A 12-year record reveals pre-growing season temperature and water table level threshold effects on the net carbon dioxide exchange in a boreal fen', Environmental Research Letters, vol. 9, 055006, 11pp.

Raddatz, R.L., Papakyriakou, T.N., Swystun, K.A., and Tenuta, M. 2009. 'Evapotranspiration from a wetland tundra sedge fen: surface resistance of peat for land-surface schemes', Agricultural and Forest Meteorology, vol. 149, pp. 851-861.

Riutta, T., Laine, J., and Tuittila, E-S. 2007. 'Sensitivity of $\mathrm{CO}_{2}$ exchange of fen ecosystem components to water level variation', Ecosystems, vol. 10, pp. 718-733.

Roulet, N.T., Lafleur, P.M., Richard, P.J.H., Moore, T.R., Humphreys, E.R., and Bubier, J. 2007. 'Contemporary carbon balance and late Holocene carbon accumulation in a northern peatland', Global Change Biology, vol. 13, pp. 397-411.

Rouse, W.R., Bello, R.L., D’Souza, A., Griffis, T.J., and Lafleur, P.M. 2002. 'The annual carbon budget for fen and forest in a wetland at Arctic treeline', Arctic, vol. 55, pp. 229-237. 
Schreader, C.P., Rouse, W.R., Griffis, T.J., Boudreau, L.D., and Blanken, P.D, 1998. 'Carbon dioxide fluxes in a northern fen during a hot, dry summer', Global Biogeochemical Cycles, vol. 12, pp. 729-740.

Syed, K.H., Flanagan, L.B., Carlson, P.J., Glenn, A.J., and van Gaalen, K.E. 2006. 'Environmental control of net ecosystem $\mathrm{CO}_{2}$ exchange in a treed, moderately rich fen in northern Alberta', Agricultural and Forest Meteorology, vol. 140, pp. 97-114.

Tanner, C.B., and Thurtell, G.W. 1969. 'Sensible heat flux measurements with a yaw sphere and thermometer: anemoclinometer measurements of Reynolds stress and heat transport in the atmospheric surface layer', TR Ecom 66-G22-F, Dept. Soil Science, Univ. Wisconsin, Madison, Wisconsin.

Tarnocai, C., Canadell, J.G., Mazhitova, G., Schuur, E.A.G., Kuhry, P., and Zimov, S. 2009. 'Soil organic carbon pools in the northern circumpolar permafrost region', Global Biogeochemical Cycles, vol. 23, GB2023, 11 pp.

Vourlitis, G.L., and Oechel, W.C. 1997. 'Landscape-scale $\mathrm{CO}_{2}, \mathrm{H}_{2} \mathrm{O}$ vapour, and energy flux of a moist-wet coastal tundra ecosystems over two growing seasons', Journal of Ecology, vol. 85 , pp. $575-590$.

Vourlitis, G.L., Harazono, Y., Oechel, W.C., Yoshimoto, M., and Mano, M. 2000. 'Spatial and temporal variations in hectare-scale net $\mathrm{CO}_{2}$ flux, respiration and gross primary production of Arctic tundra ecosystems', Functional Ecology, vol. 14, pp. 203-214.

Webb, E.K., Pearman, G., and Leuning, R. 1980. 'Correction of flux measurements for density effects due to heat and water vapour transfer', Quarterly Journal of the Royal Meteorological Society, vol. 106, pp. 85-100. 
Weltzin, J.F., Pastor, J., Harth, C., Bridgham, S.D., Updegraff, K., and Chapin, C.T. 2000. 'Response of bog and fen plant community to warming and water-table manipulations', Ecology, vol. 81, pp. 3464-3478.

Wilson, K., Goldstein, A., Falge, E., Aubinet, M. Baldocchi, D., Berbigier, P., Bernhofer, C., Ceulemans, R., Dolman, H., and Field, C. 2002. 'Energy balance closure at FLUXNET Sites'. Agricultural and Forest Meteorology vol. 113, pp. 223-243.

Wu, J., Roulet, N.T., Nilsson, M., Lafleur, P., and Humphreys, E. 2012. 'Simulating the carbon cycling of northern peatlands using a land surface scheme coupled to a wetland carbon model (CLASS3W-MWM)', Atmosphere-Ocean, vol. 50, pp. 487-506.

Wu, J., and Roulet, N.T. 2014. 'Climate change reduces the capacity of northern peatlands to absorb the atmospheric carbon dioxide: The different responses of bogs and fens', Global Biogeochemical Cycles, vol. 27, pp.1005-1024.

Zimov, S.A., Zimova, G.M., Daviodov, S.P., Daviodova, A., Voropaev, Y.V., Voropaeva, Z.F., Prosiannikov, S.F., Prosiannikova, O.V., Semiletova, I.V., and Semiletov, I.P. 1993. 'Winter biotic activity and production of $\mathrm{CO}_{2}$ in Siberian soils: a factor in the greenhouse effect', Journal of Geophysical Research, vol. 98, pp. 5017-5023. 


\section{Figure Captions}

Figure 1: Cumulative precipitation and mean daily water table position in relation to the mean sedge peat elevation (datum) for the fen at Churchill, Manitoba for DOY 160 - 320 in 2007, 2008, 2010 and 2011.

Figure 2: Cumulative gap-filled NEE $\left(\mathrm{g} \mathrm{C} \mathrm{m}^{-2}\right)$ for the fen at Churchill, Manitoba for DOY $170-284$ of 2007, 2008, 2010 and 2011.

Figure 3: Daily GPP and ER $\left(\mathrm{g} \mathrm{C} \mathrm{m}^{-2} \mathrm{~d}^{-1}\right)$ for the fen at Churchill, Manitoba for DOY 170 - 284 of 2007, 2008, 2010 and 2011.

Figure 4: a) Slow response functions for GPP for each year and daily integrated PAR, averaged for all years. Points are at noon for every fifth day.

b) Slow response function for ER for each year and daily average soil temperature at the $5 \mathrm{~cm}$ depth for 2010. Points are noon for every fifth day. There was a large rain event on DOY 236 in 2010, which raised the water table and affected the response function for several weeks, even though temperatures recovered.

Figure 5: Cumulative gap-filled net ecosystem exchange of carbon (NEE), methane flux $\left(\mathrm{F}_{\mathrm{CH} 4}\right)$ and net balance (NET), represented as carbon fluxes $\left(\mathrm{g} \mathrm{C} \mathrm{m}^{-2}\right)$ and greenhouse gas fluxes $\left(\mathrm{g} \mathrm{CO}_{2}\right.$-eq m$\left.{ }^{-2}\right)$, for the fen at Churchill, Manitoba for DOY 170 - 284 of 2007, 2008, 2010, and 2011. Note that the uncertainty in NEE among years is about $\pm 34 \mathrm{~g} \mathrm{C} \mathrm{m}^{-2}$. 


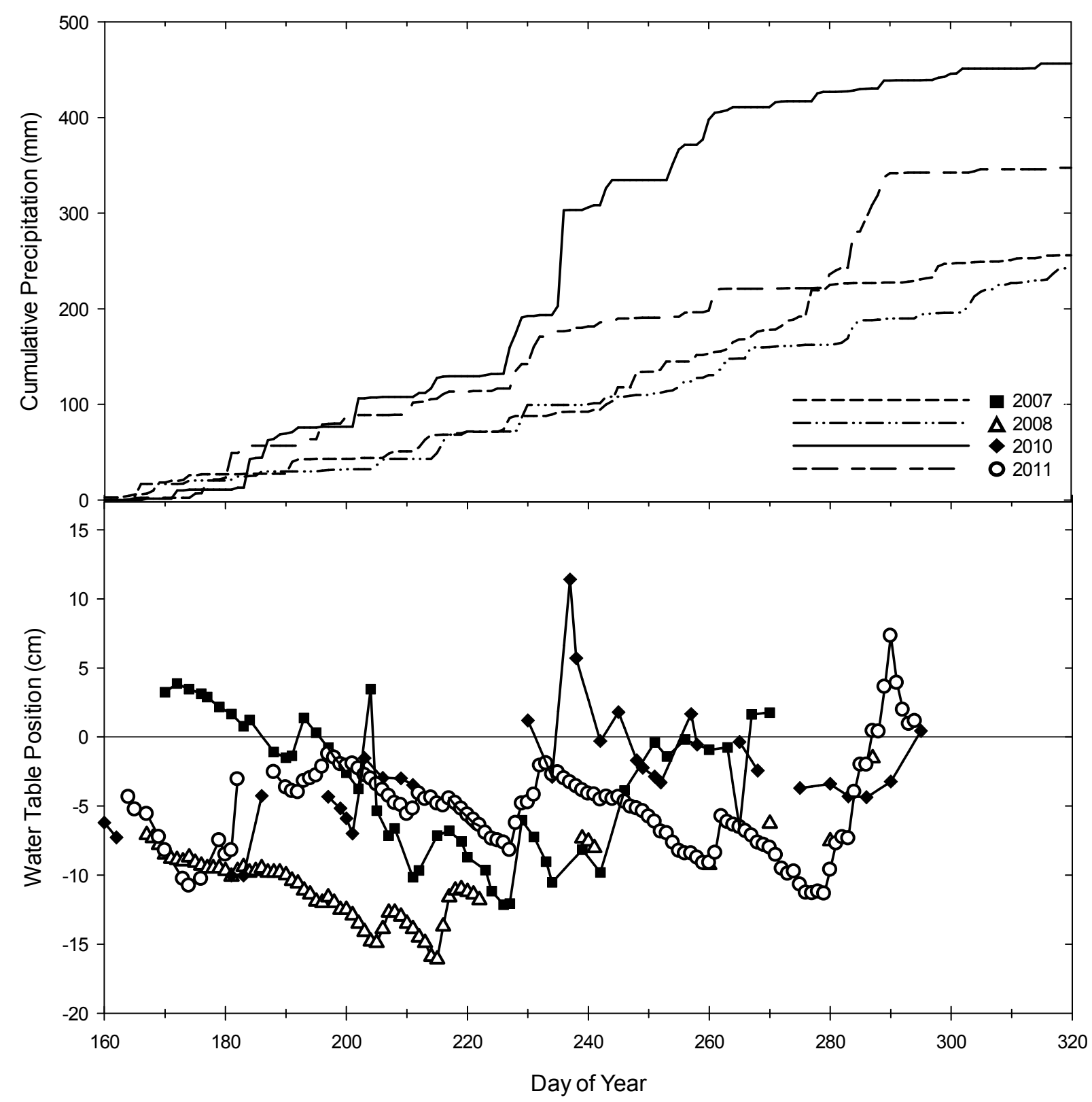

Figure 1: Cumulative precipitation and mean daily water table position in relation to the mean sedge peat elevation (datum) for the fen at Churchill, Manitoba for DOY 160 - 320 in 2007, 2008, 2010 and 2011. 


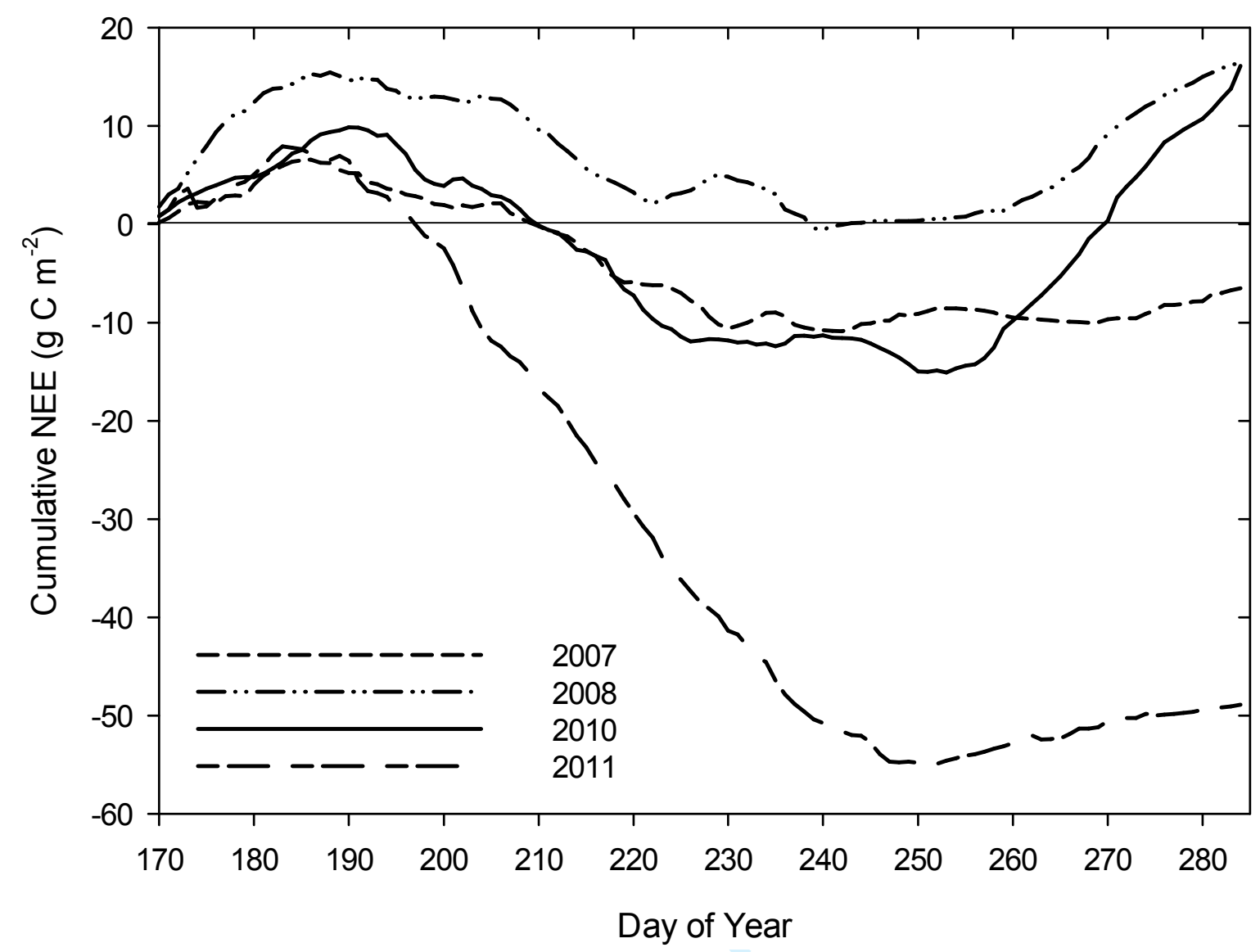

Figure 2: Cumulative gap-filled NEE $\left(\mathrm{g} \mathrm{C} \mathrm{m}^{-2}\right)$ for the fen at Churchill, Manitoba for DOY $170-284$ of 2007, 2008, 2010 and 2011. 


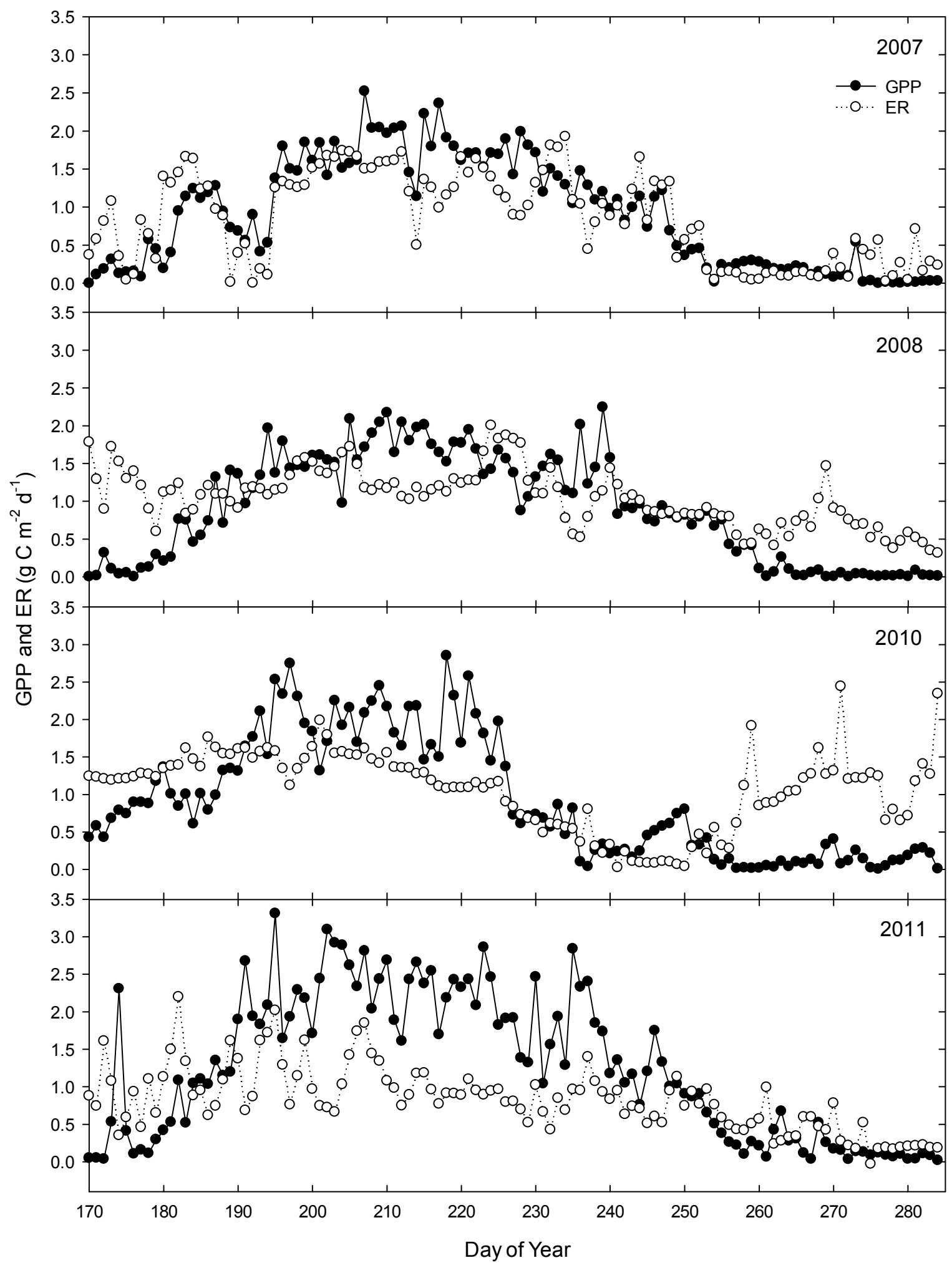

Figure 3: Daily GPP and ER $\left(\mathrm{g} \mathrm{C} \mathrm{m}^{-2} \mathrm{~d}^{-1}\right)$ for the fen at Churchill, Manitoba for DOY $170-284$ of 2007, 2008, 2010 and 2011. 

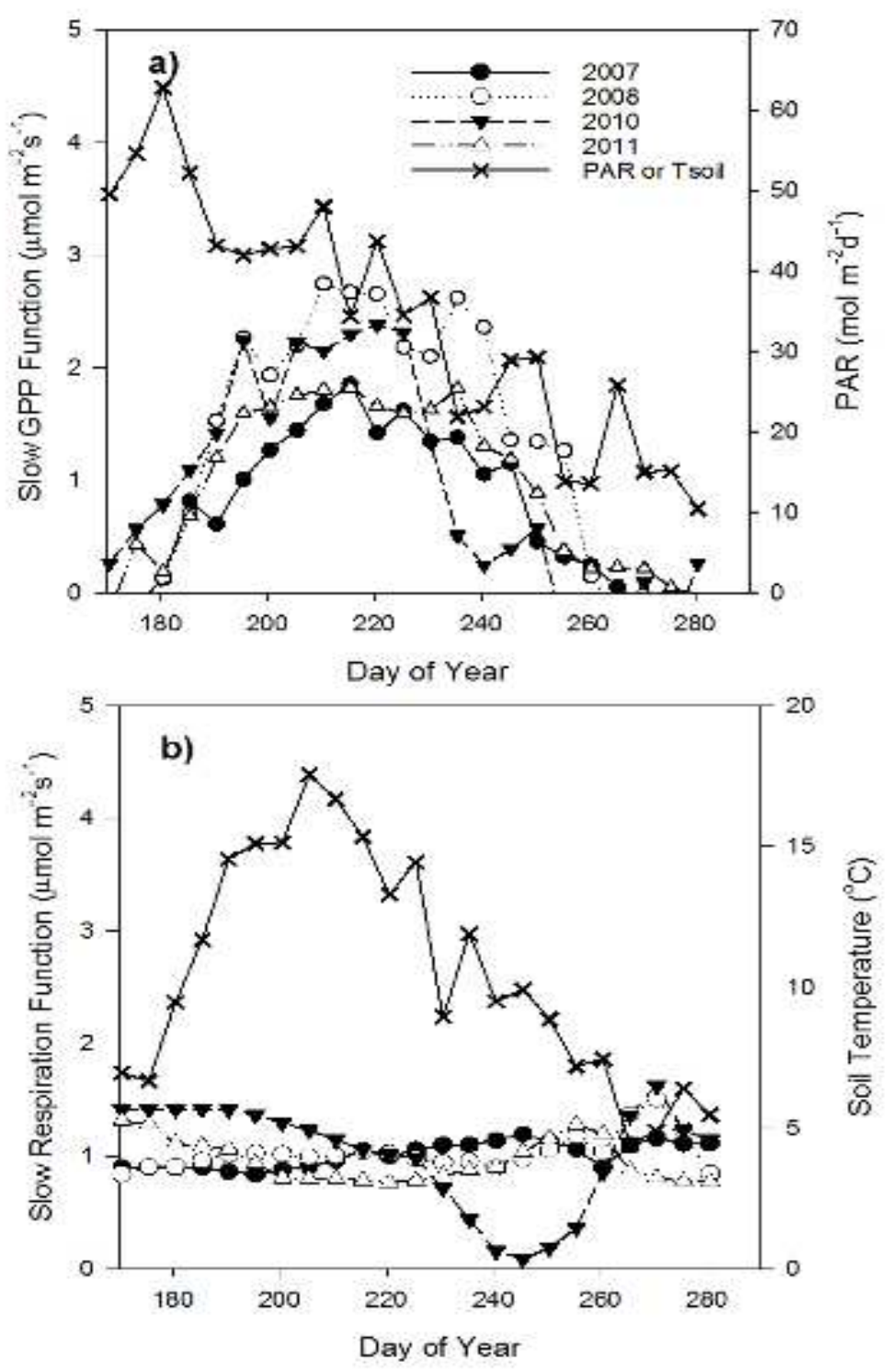

Figure 4: a) Slow response functions for GPP for each year and daily integrated PAR, averaged for all years. Points are at noon for every fifth day.

b) Slow response function for ER for each year and daily average soil temperature at the $5 \mathrm{~cm}$ depth for 2010. Points are noon for every fifth day. There was a large rain event on DOY 236 in 2010, which raised the water table and affected the response function for several weeks, even though temperatures recovered. 


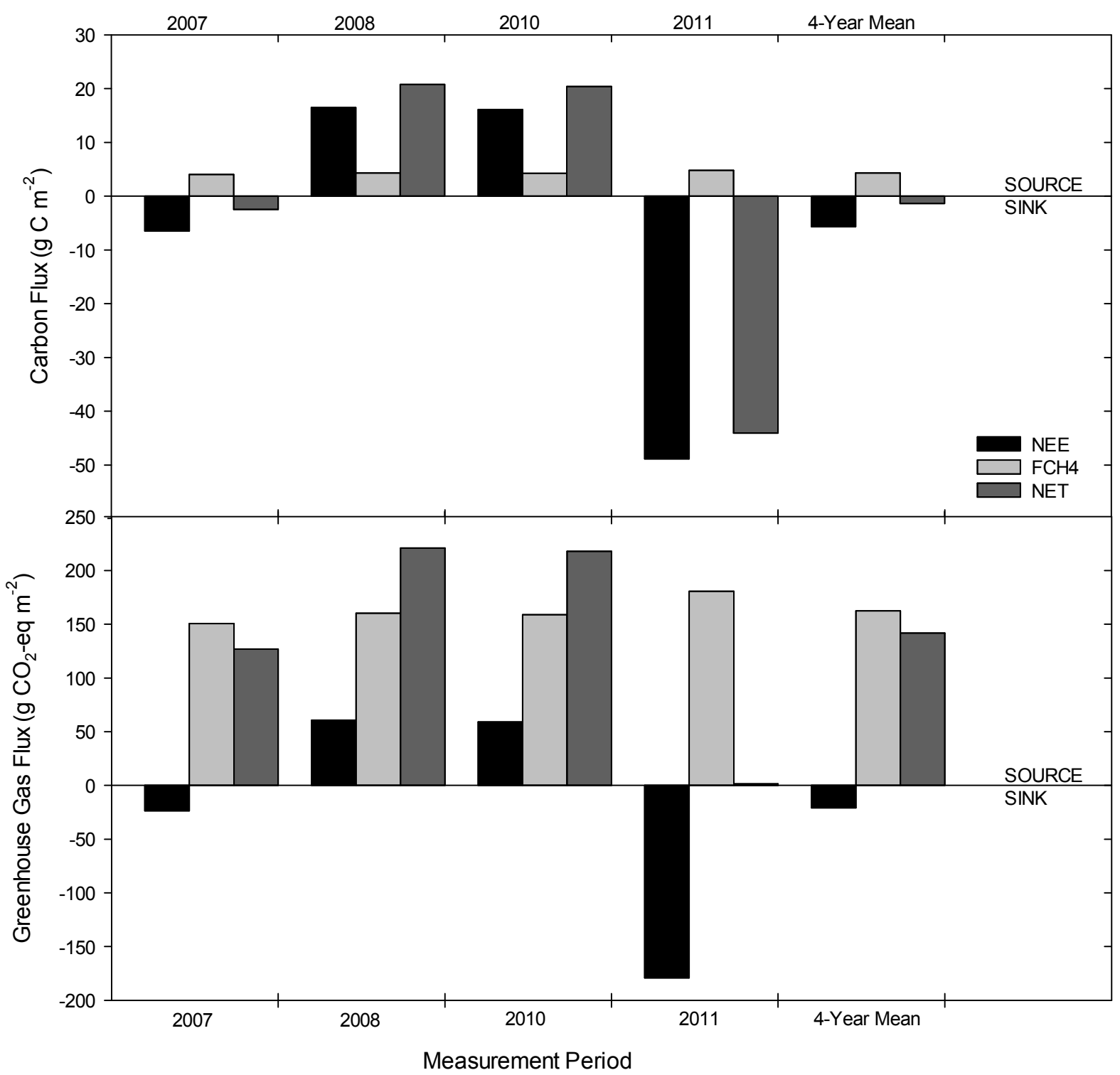

Figure 5: Cumulative gap-filled net ecosystem exchange of carbon (NEE), methane flux $\left(\mathrm{F}_{\mathrm{CH} 4}\right)$ and net balance (NET), represented as carbon fluxes $\left(\mathrm{g} \mathrm{C} \mathrm{m}^{-2}\right)$ and greenhouse gas fluxes $\left(\mathrm{g} \mathrm{CO}_{2}\right.$-eq m$\left.{ }^{-2}\right)$, for the fen at Churchill, Manitoba for DOY 170 - 284 of 2007, 2008, 2010, and 2011. Note that the uncertainty in NEE among years is about $\pm 34 \mathrm{~g} \mathrm{C} \mathrm{m}^{-2}$. 
Table 1: Monthly average air temperature and total precipitation at the Churchill airport from May to November compared to the 1981 - 2010 monthly climate normal (Environment Canada, 2014), onset of spring melt and fall freeze-up, and total thaw period days at Churchill, Manitoba.

\begin{tabular}{rrrrrr}
\hline & $\mathbf{2 0 0 7}$ & $\mathbf{2 0 0 8}$ & $\mathbf{2 0 1 0}$ & $\mathbf{2 0 1 1}$ & Normal \\
\hline Average Air Temperature ( $\left.{ }^{\circ} \mathbf{C}\right)$ & & & & & \\
May & 1.3 & -0.5 & -1.1 & -2.2 & $\mathbf{- 1}$ \\
Jun & 5.4 & 7.3 & 7.7 & 7.7 & 7 \\
Jul & 15.1 & 12.5 & 14.0 & 14.2 & $\mathbf{1 2 . 7}$ \\
Aug & 11.5 & 13.8 & 11.1 & 13.0 & $\mathbf{1 2 . 3}$ \\
Sep & 5.2 & 5.2 & 6.8 & 10.3 & $\mathbf{6 . 4}$ \\
Oct & 0.8 & 1.5 & 1.7 & 1.7 & $\mathbf{- 1 . 2}$ \\
Nov & -13.9 & -9.3 & -8.1 & -9.3 & $\mathbf{- 1 2 . 7}$ \\
Season & 3.6 & 4.4 & 4.6 & 5.1 & $\mathbf{3 . 4}$ \\
& & & & & \\
Total Precipitation (mm) & & & & & \\
May & 26.0 & 21.0 & 40.9 & 63.5 & $\mathbf{3 0}$ \\
Jun & 35.8 & 43.0 & 12.5 & 42.9 & $\mathbf{4 4 . 2}$ \\
Jul & 30.4 & 20.1 & 71.9 & 59.8 & $\mathbf{5 9 . 8}$ \\
Aug & 52.4 & 81.5 & 181.4 & 80.2 & $\mathbf{6 9 . 4}$ \\
Sept & 77.0 & 53.0 & 54.2 & 24.2 & $\mathbf{6 9 . 9}$ \\
Oct & 46.4 & 50.4 & 27.2 & 102.0 & $\mathbf{4 8 . 4}$ \\
Nov & $13.0 *$ & 7.0 & 6.9 & 12.8 & $\mathbf{3 5 . 5}$ \\
Season & $281.0 *$ & 276.0 & 395.0 & 385.4 & $\mathbf{3 8 7 . 2}$ \\
& & & & & \\
Thawed Period (days) & 151 & 149 & 161 & 141 & \\
Melt Onset (DOY) & 146 & 144 & 129 & 150 & \\
\hline & & & & & \\
\hline
\end{tabular}

$*=$ incomplete data 